\title{
Influence of ghrelin on rat pituitary GH3 cell line proliferation
}

\author{
Małgorzata Chmielewska ${ }^{1 *}$, Mirosław Andrusiewicz $^{1 *}$, Aleksandra Żbikowska', \\ Katarzyna Kątniak', Agnieszka Sadowska', Grażyna Arasimowicz-Banaszak', \\ Sławomir Graczyk ${ }^{2}$, Ryszard Waśko ${ }^{3}$, Małgorzata Kotwicka ${ }^{1}$ \\ ${ }^{1}$ Department of Cell Biology, Poznan University of Medical Sciences, Poland \\ ${ }^{2}$ Department of Mother's and Child's Health, Poznań, Poland \\ ${ }^{3}$ Department of Endocrinology, Metabolism and Internal Medicine, Poznan University of Medical Sciences, Poland \\ * These authors contributed equally to the completion of this study
}

\begin{abstract}
Introduction. Human ghrelin is the endogenous ligand of the growth hormone secretagogue receptor type 1a (GHSR1a). It is suggested that ghrelin is involved in pituitary adenomas pathogenesis. There are inconsistent data regarding the effect of ghrelin on cell proliferation. In this study the outcome of ghrelin in the rat pituitary adenoma GH3 cell line on morphology and proliferation ratio was evaluated. The ghrelin receptor (Ghsr) mRNA expression in $\mathrm{GH} 3$ cell line was established as well, because it was found that heterogeneous expression pattern characterized physiological and pathological conditions of tissues of different origin.

Material and Methods. Suitable experimental model pituitary tumor (rat GH3 cell line) was stimulated with ghrelin in the final concentrations $10^{-12} \mathrm{M}, 10^{-9} \mathrm{M}$ and $10^{-6} \mathrm{M}$. Reverse transcription followed by real time polymerase chain reaction was used for ghrelin receptor gene transcript detection. The morphology as well as cell cycle of those cells were analyzed using Axio Vert.A1 Microscope (Zeiss) and BD FACSCalibur' flow cytometer (Beckton Dickinson), respectively. The percentages of cells in the $G_{0} / G_{1}, S, G_{2} / M$ cycle phases were evaluated using the ModFit"' software (Verity Software, Inc., USA).

Results. Ghsr mRNA presence was confirmed in GH3 cells. Ghrelin did not affect conspicuously GH3 cells morphology, however the ghrelin-induced proliferation index increase was caused by both decline of $G_{0} / G_{1}$ phases cells count and increase those being in $S+G_{2} / M(p<0.05)$.

Conclusions. In conclusion, this study indicates that ghrelin stimulates $\mathrm{GH} 3$ cells proliferation and may play role in pituitary tumorigenesis via an autocrine/paracrine pathway.
\end{abstract}

Keywords: ghrelin; ghrelin receptor; proliferation, pituitary adenoma.

\section{Introduction}

The role of ghrelin (GHRL) in pituitary tumorigenesis is unexplained so far. Expression of the receptor through which ghrelin mediate its effects was identified in different types of pituitary tumors, including the majority of somatotropinomas, in which the highest expression of growth hormone (GH) secretagogues receptor (GHSR) was detected [1]. There are reports suggesting that ghrelin may be an antiproliferative factor. Its inhibitory impact on proliferation was confirmed in studies conducted on cancer cell lines of the thyroid gland, breast, pituitary and lungs [2]. Other studies suggest that it may also stimulate cells proliferation $[3,4]$.

$\mathrm{GH} 3$ cell line derived from rat's anterior pituitary tumor is an in vitro model to study pituitary adenoma 
development. In the previous studies $\mathrm{GH} 3$ cells were also used as a suitable cell line model regarding human somatotropinoma. There are only few reports concerning the proliferative effect of ghrelin on somatotropic cells of above mentioned cancer cell line [5-7]. Nanzer et al. found that both the acylated and non-acylated ghrelin stimulated proliferation of cells of GH3 cancer cell line [5]. Stevanovic et al. and Milosević et al. after administration of ghrelin into rats cerebral ventricles, found that the weight of the pituitary, the volume of both, $\mathrm{GH}$-producing cells and their nuclei increased. This suggests enhanced potency of ghrelin, which may contribute to its transcriptional activity $[6,7]$.

In this study we examined the Ghsr gene expression in $\mathrm{GH} 3$ cell line, and whether ghrelin affects somatotroph pituitary rat adenoma GH3 cell line morphology and proliferation ratio.

\section{Material and Methods}

\section{Cell culture and stimulation}

All experiments were performed on rat pituitary adenoma $\mathrm{GH}_{3}$ cell line obtained from the American Type Culture Collection (ATCC, USA). Cells were cultured in Ham's F-10 medium (Cytogen, Germany) supplemented with $2.5 \%$ fetal bovine serum (FBS, Biowest, USA), $15 \%$ horse serum (Sigma Aldrich, USA), $100 \mu \mathrm{g} / \mathrm{mL}$ penicillin, $100 \mu \mathrm{g} / \mathrm{mL}$ streptomycin (Cytogen, Germany) and $2 \mathrm{mM}$ L-glutamine (Cytogen, Germany). Cell line was maintained in aseptic conditions at $37^{\circ} \mathrm{C}, 5 \% \mathrm{CO}_{2}$ in a humidified incubator and confirmed free of mycoplasma contamination through regular testing (Mycoplasma PCR Test Kit, Applichem, Germany). Cells were cultured until $90 \%$ confluence. At this point they were washed with phosphate buffered saline (PBS, Biowest, USA) and detached from culture dishes with $0.25 \%$ trypsin solution (Biowest, USA). After 3 minutes of incubation trypsin was removed, complete growth medium was added and resuspended cells were transferred into sterile 6 -well plates at a density of 100,000 cells per well.

\section{Ghsr gene expression analysis}

GH3 cells prepared as described before were used for Ghsr expression analysis using reverse transcription followed by real time polymerase chain reaction. This method was performed to analyze the expression in qualitative and not quantitative way, because of its sensitivity and specificity (provided with the TaqMan ${ }^{\circledR}$ probes).

\section{RNA isolation and reverse transcription}

Total RNA was extracted from $\mathrm{GH} 3$ cells using ready-to-use RNA 3-zone reagent (Novazym, Poland) according to manufacturer's protocol with modification in RNA precipitation step performed in $-80^{\circ} \mathrm{C}$ instead of room temperature. The quality of total RNA and its concentration were analyzed with the use of NanoDrop $^{\text {TM }}$ ND-1000 spectrophotometer (Thermo Fisher Scientific, USA). The integrity was evaluated by ribosomal RNA bands analysis after electrophoretic separation of $1 \mu \mathrm{g}$ RNA in $0.8 \%$ agarose gel in $1 \mathrm{xFA}$ buffer (20 mM 3-[N-morpholino]-propanesulfonic acid (MOPS) (free acid), $5 \mathrm{mM}$ sodium acetate, $1 \mathrm{mM}$ EDTA, pH 7.0, Sigma-Aldrich, USA) and presence of ethidium bromide and $0.8 \%$ paraformaldehyde (Avantor, Poland) providing denaturing conditions.

RNA was reversely transcribed to CDNA in three-step reaction conducted in accordance with Transcriptor Reverse Transcriptase manufacturer's protocol (Roche, Germany) in the total volume of $10 \mu \mathrm{L}$. In the first step mixture of: $5 \mathrm{mM}$ oligo(d) $\mathrm{T}_{10}$ (Genomed, Poland), RNA $(0.5 \mu \mathrm{g})$ and RNase-, DNase- and pyrogen-free water (Life Science) was denatured 10 $\min$ at $65^{\circ} \mathrm{C}$. Subsequently, the samples were cooled on ice. In the second step of incubation $10 \mathrm{U} / \mu \mathrm{L}$ ribonuclease inhibitor (RNasin, Roche), $10 \mathrm{U} / \mu \mathrm{L}$ of Transcriptor reverse transcriptase (Roche), $100 \mathrm{mM}$ dNTPs (Novayzm) and $1 x$ reaction buffer (Roche) were added. Thermal profile was as follows: 10 minutes at $25^{\circ} \mathrm{C}$ (binding of primers to the template), 60 minutes at $55^{\circ} \mathrm{C}$ (cDNA synthesis step) and 5 minutes at $85^{\circ} \mathrm{C}$ (enzyme denaturation). Until real time PCR was performed cDNA was stored in $-20^{\circ} \mathrm{C}$.

\section{TaqMan ${ }^{\circledR}$ real time polymerase chain reaction}

RNA expression pattern analysis was performed using the LightCycler 2.0 carousel-based system. Real time PCR for the Rat (Rattus Norvegicus) Ghsr (GeneBank: NM_032075.3) was conducted with TaqMan ${ }^{\oplus}$ hydrolysis probes (Roche) and primers (Genomed, Poland) designed with the Universal ProbeLibrary assay design on-line software (Roche). Sense and antisense primers and the fluorescent probes numbers were: $5{ }^{\prime}-A G$ GAAGCTATGGCGGAGAC-3' and 5'-GAAAGCAAACACCACCACAGC-3', probe \#112 (Roche cat. № 04693469001). Rat ready to use Actb ( $\beta$-actin) Reference Gene Assay (Roche assay $N^{\circ}$ 5046203001) was used as internal control and for relative concentration ratio evaluation. Reactions were performed in the total volume of 20 $\mu \mathrm{L}$ reagent mix containing: 1x LightCycler ${ }^{\boxplus}$ FastStart $^{\mathrm{TM}}$ TaqMan ${ }^{\oplus}$ Probe Master mix (Roche), $5 \mu \mathrm{L}$ of cDNA, 0.5 

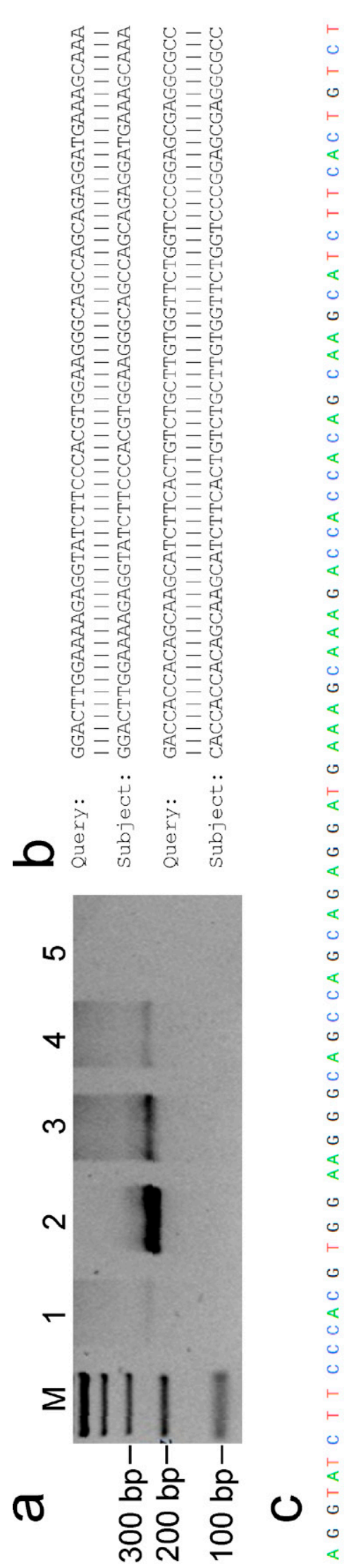
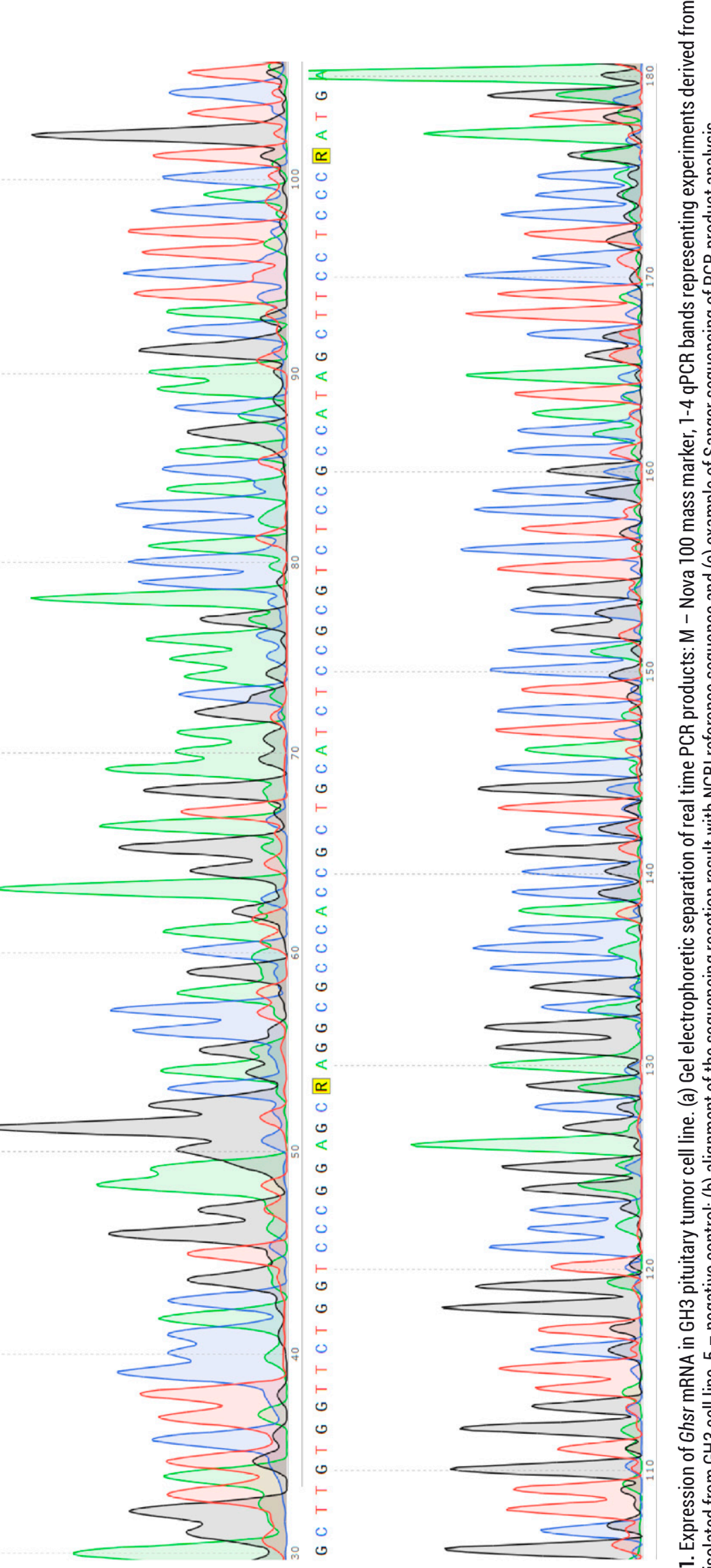

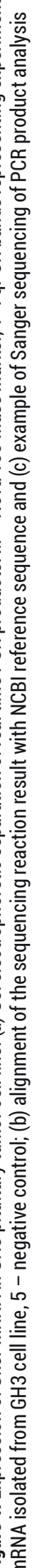


$\mathrm{mM}$ of each primer (Genomed) and $0.1 \mathrm{mM}$ hydrolysis probe (Roche).

$5 \mu \mathrm{l}$ of qPCR product was analyzed and compared with the Nova 100 molecular mass marker (Novazym) after electrophoretic separation in $2 \%$ agarose gel (FMC BioProducts, Rockland, ME USA) containing $1 \mathrm{x}$ Tris/Boric Acid/EDTA (TBE) buffer (Bio-Rad) at presence of $500 \mathrm{ng} / \mathrm{ml}$ ethidium bromide (Sigma-Aldrich).

The presence of $\operatorname{TaqMan}^{\circledR}$ hydrolysis probes ensured the specifity of the reaction. ZymoClean ${ }^{\mathrm{TM}}$ gel DNA recovery kit (Zymo Research, USA) was used for PCR products gel recovery and purification followed by Sanger sequencing analysis (Genomed).

\section{Cell morphology}

Cells morphology was evaluated using using Axio Vert. A1 microscope (Zeiss, Germany) after 24 and 48 hours of incubation with different ghrelin concentrations: $10^{-12} \mathrm{M}, 10^{-9} \mathrm{M}$ and $10^{-6} \mathrm{M}$.

\section{Cell cycle analysis}

Cells were treated with ghrelin for cell cycle analysis in different final concentrations: $10^{-12} \mathrm{M}, 10^{-9} \mathrm{M}$ and $10^{-6}$ $\mathrm{M}$. All analyses were made in triplicates. Control contained non-stimulated cells. Cells prepared due to this procedure were used for further investigations.

After 24 and 48 hours of incubation cells were harvested as described above, washed in PBS and fixed in $70 \%$ ethanol (Avantor, Poland) at $4^{\circ} \mathrm{C}$ for $30 \mathrm{~min}$ utes. Next, cells were pelleted by centrifugation, resuspended in $1 \mathrm{~mL}$ of PBS containing RNase $A(10 \mathrm{mg} / \mathrm{mL})$ and incubated at room temperature for 30 minutes. After that, cells were centrifuged and the pellet was suspended in $500 \mu \mathrm{L}$ propidium iodide staining solution $(50 \mu \mathrm{g} / \mathrm{mL})$ for 1 hour at room temperature in the dark. Subsequently, cell samples were analyzed with the use of the BD FACSCalibur ${ }^{\text {TM }}$ flow cytometer (Becton Dickinson, USA). For each experiment 10,000 cells were examined. The fluorescence of propidium iodide was excited using an argon laser (488 $\mathrm{nm}$ ) and emission of red fluorescence was detected in the FL3 channel (>650 nm). Data were collected and analyzed using CellQuest Pro software (v.5.2.1) (Becton-Dickinson). The percentages of cells in the sub $G_{0}, G_{0} / G_{1}, S, G_{2} / M$ cycle phases were evaluated using the ModFit ${ }^{\mathrm{TM}}$ software (Verity Software, Inc., USA). After flow cytometric analysis, Modfit software was used to calculate the proliferation index $(\mathrm{PI})\left(\mathrm{S}+\mathrm{G}_{2} \mathrm{M} / \mathrm{G}_{0} \mathrm{G}_{1} \times 100\right)$ by dividing the percentages of proliferating cells (cells in $S$ and $G_{2} / M$ phases) by non-proliferating cells (cells in $G_{0} / G_{1}$ phase).

\section{Statistical analysis}

The data were analyzed using the Statistica 10 software (StatSoft Inc., USA). The distributions of the data were assessed by the Shapiro-Wilk test. Due to nonparametric distributions Kruskal-Wallis test with Dunn's post-hoc test were applied. The data were calculated for three separate experiments and shown as mean \pm standard deviation (SD). Statistical significance was taken at $p<0.05$.

\section{Results}

\section{Ghsr gene expression analysis}

Presence of Ghsr gene was confirmed after reverse transcription real tie polymerase chain reaction with the use of TaqMan ${ }^{\circledR}$ hydrolysis probes by gel electrophoresis (Figure 1a) and Sanger sequencing (Figure 1c). The size of the electrophoretic separated DNA band as well as alignment (Figure $\mathbf{1 b}$ ) of the sequencing reaction result scored entirely with this deposited in NCBI database and confirmed the identity with Ghsr GeneBank $\mathrm{N}^{0}$ NM_032075.3

\section{Ghrelin and $\mathrm{GH} 3$ cells morphology}

$\mathrm{GH} 3$ cells were loosely adherent with floating clusters and exhibited differences in their morphology was culture time-dependent. After the attachment to the Petri dish, the cells were characterized by a spherical shape which has changed to more polygonal with increasing cell confluence (Figure 2). Ghrelin did not affect GH3 cells morphology regardless of ligand concentration and incubation time.

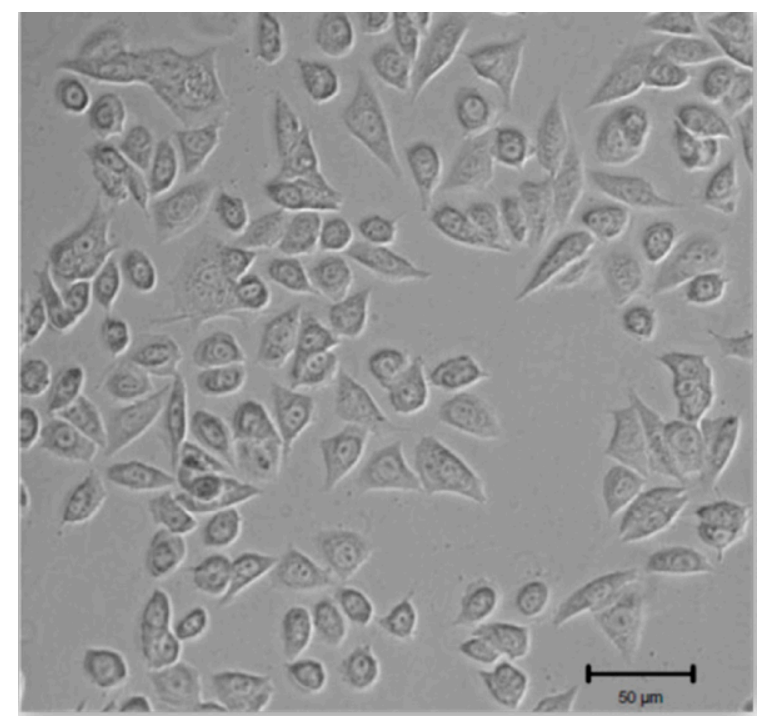

Figure 2. GH3 pituitary tumor cell line morphology. Representing example of non-stimulated cells 

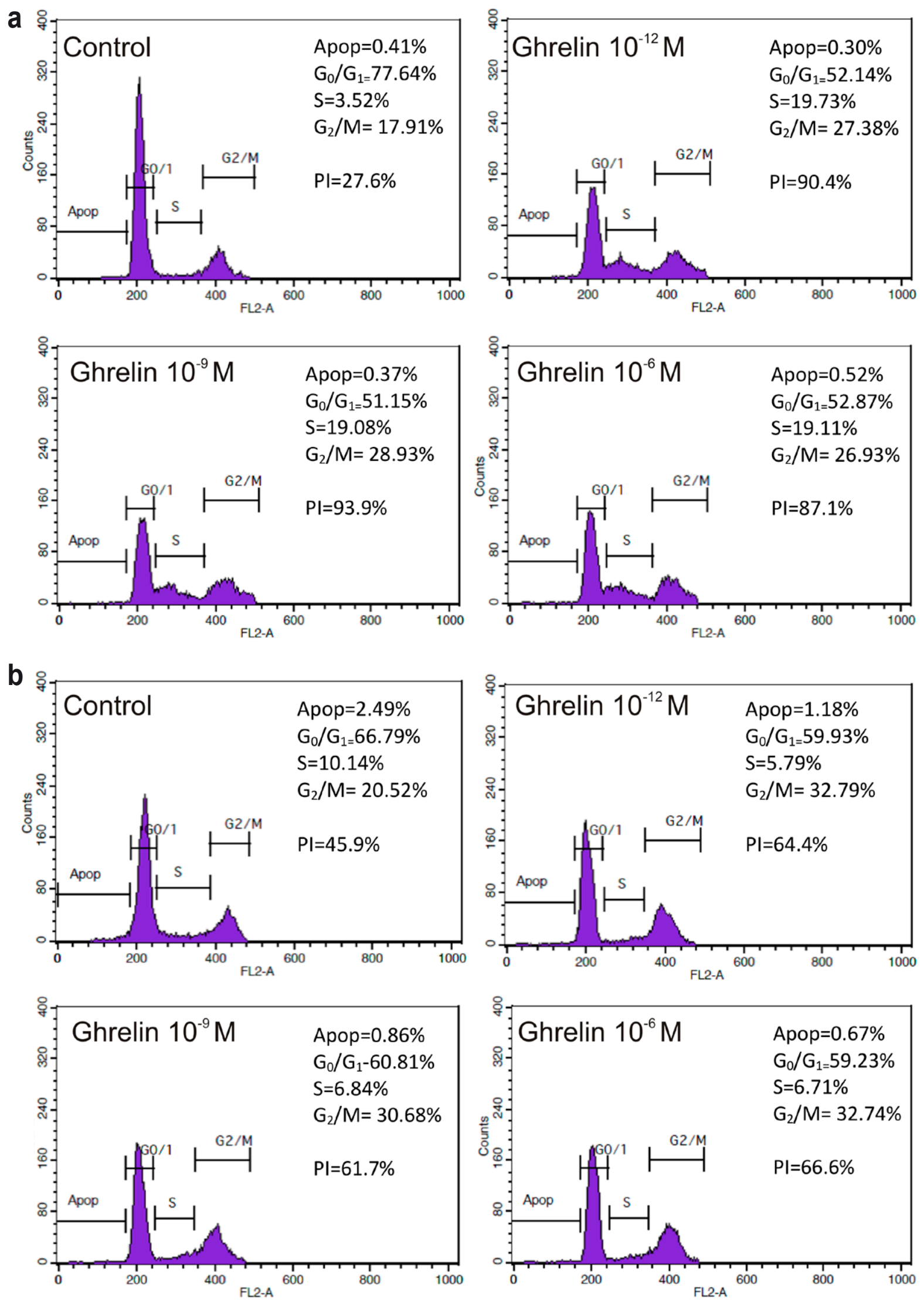

Figure 3. Representative example of cell cycle redistribution of $\mathrm{GH} 3$ cells after ghrelin stimulation. $\mathrm{GH} 3$ cells ware incubated with ghrelin in different doses $\left(10^{-12}, 10^{-9}\right.$ or $\left.10^{-6} \mathrm{M}\right)$ for 24 or $48 \mathrm{~h}$. The cell cycle was analyzed using FACSCalibur ${ }^{\text {rm }}$ flow cytometer. The percentages of cells in the sub $G_{0}, G_{0} / G_{1}, S, G_{2} / M$ cycle phases were evaluated using the Modfit software. PI - proliferation index $\left(S+G_{2} M / G_{0} G_{1} x 100\right)$, Apop - apoptotic cells percentage 
Ghrelin and $\mathrm{GH} 3$ cell cycle

In the control group no changes in the cell cycle of $\mathrm{GH} 3$ cells were observed during 48 hours observation period ( $p=N S$, Figure 3). The proliferation index (PI) ranged from $26 \%$ to $44 \%(29.3 \pm 3.5 \%)$ after $24 \mathrm{~h}$ and $25 \%$ to $44 \%$ $(31.2 \pm 6.4 \%)$ after $48 \mathrm{~h}$. Compared to control group, an increase of $\mathrm{PI}$ was observed $24 \mathrm{~h}$ after stimulation with different ghrelin concentrations: $29.3 \pm 3.5$ vs $79.6 \pm$ $9.5 \%(\mathrm{p}<0.0001)$ at a concentration $10^{-12} \mathrm{M}, 29.3 \pm 3.5$ vs $90.5 \pm 2.3 \%(\mathrm{p}<0.0001)$ at $10^{-9} \mathrm{M}$ and $29.3 \pm 3.5$ vs $88.0 \pm 1.8 \%(p<0.001)$ at $10^{-6} \mathrm{M}$. Within the used range of ghrelin concentrations, we did not observe dose-dependent changes. An increase of PI was also observed $48 \mathrm{~h}$ after ghrelin stimulation and was as follows: 31.2 \pm 6.1 vs $59.2 \pm 4.9 \%(p<0.0001)$ at a concentration $10^{-12} \mathrm{M}, 31.2 \pm 6.1$ vs $57.0 \pm 7.3 \%(\mathrm{p}<0.0001)$ at $10^{-9} \mathrm{M}$ and $31.2 \pm 6.1$ vs $59.2 \pm 8.27 \%(p<0.001)$ at $10^{-6} \mathrm{M}$, however, as well as in case of $24 \mathrm{~h}$ observation, there were not visible dose-dependent changes (Figure 3). Observed increase in the proliferation index was due to both a decrease in $G_{0} / G_{1}$ cell count and the increase in the $S+G_{2} / M$ cells' population (Figure 4 ).

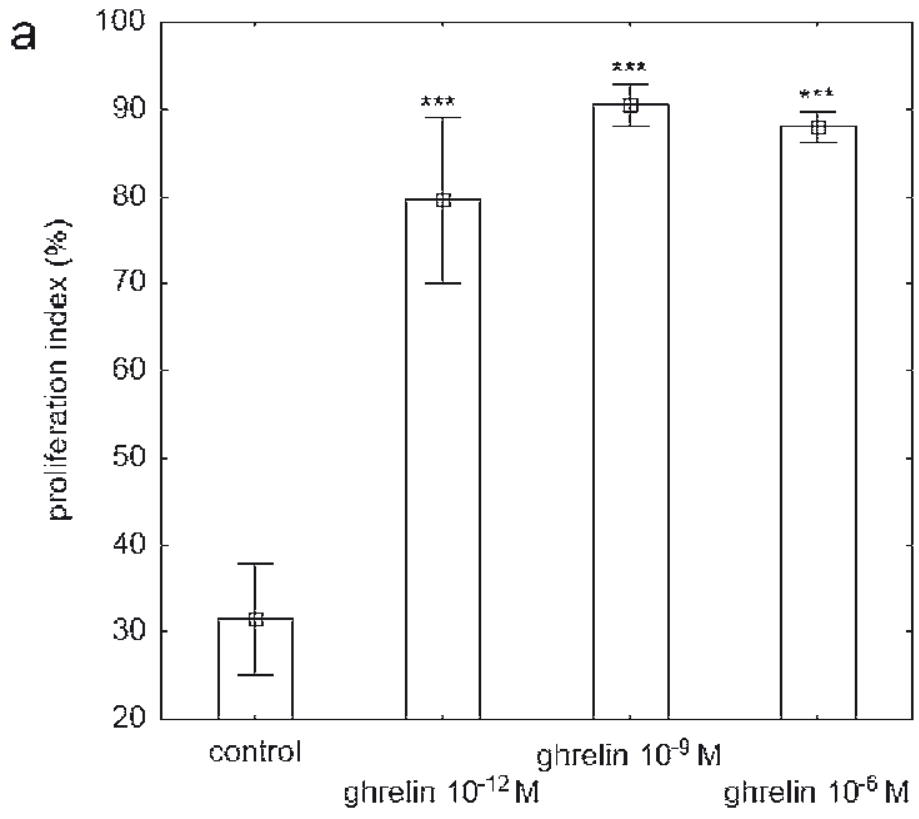

(Milear

$\mathrm{b}$

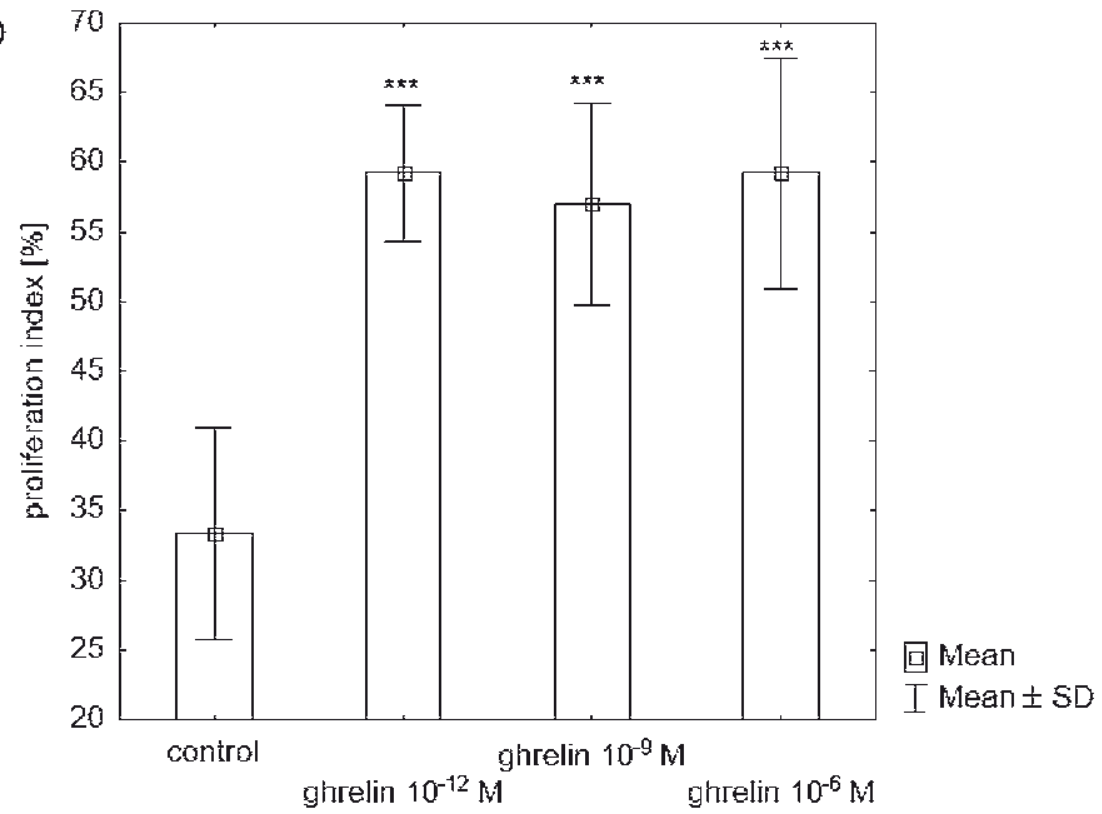

Figure 4. Dose-dependent effect of ghrelin stimulation in $\mathrm{GH} 3$ cells. Proliferation index (a) 24 hours and (b) 48 hours after stimulation. Results are shown as means \pm standard deviation. Significance is referred to the control $\left({ }^{* * *} \mathrm{P}<0.001\right)$ 


\section{Discussion}

Several studies have demonstrated that ghrelin and its receptors are expressed in pituitary adenomas [8-10]. In this study, we aimed to establish ghrelin influence on somatotropic cells morphology and proliferation. Ghrelin did not affect $\mathrm{GH} 3$ cells morphology regardless of ligand concentration and incubation time. However, ghrelin significantly increased GH3 cells proliferation index, as a result of decreased cells count population in $G_{0} / G_{1}$ phase and increased $S+G_{2} / M$. In human cells, these effects may be mediated through the GHSRla, corresponding to this shown to be expressed in $\mathrm{GH} 3$ pituitary somatotroph tumor cell line (Ghsr).

Published data regarding ghrelin impact on cells proliferation revealed either stimulation or inhibition. Our results are in line with previously published data concerning $\mathrm{GH} 3$ cell line $[5,11]$ as well as data concerning different cell types of: adrenocortical tumor [12], hepatoma [4], prostate tumors [11], neural [13], pre-adipocytes [14], osteoblasts [12] or cardiomyocytes [15]. Nanzer et al. in a study applying ${ }^{3} \mathrm{H}$-thymidine incorporation assay demonstrated that ghrelin showed stimulating impact on rat somatotroph pituitary tumor cells proliferation. It was suggested that extracellular signal-regulated kinase (ERK) was involved in this mechanism. Desoctanoyl ghrelin showed a similar effect as octanoylated form [5]. Baldanzi et al. suggest that ghrelin and des-acyl ghrelin inhibit cell death through ERK-1/2 an PI3-kinase/AKR. Baldanzi shown that ghrelin stimulates tyrosine phosphorylation and activates ERK-1/2 and Akt [15]. Activation of ERK-1/2 by ghrelin was observed previously by Murata et al. [4]. The authors postulated that, independent of its acylation, ghrelin gen products may act as a survival factor [15]. Tian et al. demonstrated that nitric oxide (NO) blocked ghrelin-activated $\mathrm{GH} 3$ cells proliferation. The mechanism of $\mathrm{NO}$ action was mediated by inhibition of extracellular signal-regulated kinase 1/2 [16].

It is postulated that ghrelin impact on $\mathrm{GH} 3$ cells proliferation involves Ghsr receptor [5]. The GHSR is encoded by a single-copy gen located on chromosome 3 in humans, whose alternative splicing can generate two mRNA splice variants, GHSRTa and GHSRTb. The functional activity of GHSR1b remains to be fully elucidated. GHSR1a is the receptor responsible for intracellular acylated-ghrelin transduction signal pathway [17]. However, some authors postulate that ghrelin impact on cells proliferation involves other systems of signal transduction [9, 18-20]. Volante et al. described the presence of ghrelin binding sites in cellular membrane of human thyroid neoplastic cells, however the GHSR1a and GHSRTb presence was not observed [19]. Nanzer et al. suggested that ghrelin stimulate cell proliferation directly via the MAPK pathway involving the GHSR1a [5].

Anti-proliferative ghrelin effect was described in thyroid [19], breast [2] or pituitary [21] neoplastic cell lines. Either acylated or non-acylated ghrelin was studied $[2,22]$. This indicates that non-acylated ghrelin, previously considered inactive due to lack of $\mathrm{GH}$ secretion stimulation, manifested its biological activity $[12,15,21]$.

We observed that ghrelin stimulated $\mathrm{GH} 3$ cell proliferation in a way that was not directly dose-dependent. In fact, after $24 \mathrm{~h}$ incubation, the maximal stimulatory effect of ghrelin was observed at the $10^{-9} \mathrm{M}$ but not at the highest concentration of $10^{-6} \mathrm{M}$. After $48 \mathrm{~h}$ incubation, the reaction was not also dose-dependent. Maccarinelli et al. studied the effect of ghrelin $\left(10^{-11}-10^{-8}\right.$ $\mathrm{M})$ on proliferation and differentiation of osteoblastic cells and observed maximal stimulatory effect at $10^{-10}$ $\mathrm{M}$ but not at higher concentrations. Those authors speculate that ghrelin dose increase leads to another receptor subtype representing inhibitory proliferative activity recognition [23]. On the other hand, Tian et al. found that ghrelin induced the $\mathrm{GH} 3$ cells proliferation in a dose-dependent manner after $48 \mathrm{~h}$ incubation. They used bromodeoxyuridine ( $\mathrm{BrdU}$ ) assay to determine the proliferation of $\mathrm{GH} 3$ cell. Their results revealed that after $48 \mathrm{~h}$ incubation, ghrelin increased the incorporation of BrdU into $\mathrm{GH} 3$ cells in a dose-dependent manner (with significant responses to concentration ranging from $10^{-9} \mathrm{M}$ to $10^{-6} \mathrm{M}$ ) [26].

The proliferation index was assessed to evaluate cell population ratio in each phase of cell cycle. The observed increase of the proliferation index was due to both: decrease of $G_{0} / G_{1}$ cell count and increase of the $S+G_{2} / M$ cells population. In the BrdU method, an analog of the DNA precursor thymidine is incorporated into newly synthesized DNA by the cells entering and progressing through the $S$ (DNA synthesis) phase of the cell cycle. The difference between the techniques may be responsible for the small discrepancy of the results. However, both techniques confirmed stimulating effect of ghrelin on $\mathrm{GH} 3$ cells proliferation.

In conclusion, we used GH3 cells as a model of $\mathrm{GH}$-releasing adenoma in vitro. We demonstrated that $\mathrm{GH} 3$ cell line express $\mathrm{Ghsr}$ receptor. We showed that ghrelin significantly stimulated $\mathrm{GH} 3$ cells proliferation and may play a role in pituitary tumorigenesis via an autocrine/paracrine pathway.

\section{Acknowledgements}

Conflict of interest statement

The authors declare no conflict of interest. 


\section{Funding sources}

This research was funded by the National Science Centre Poland [grant No. NN 402523 040]. The funder had no role in study design, data collection and analysis, decision to publish, or preparation of the manuscript.

\section{References}

1. Arvat E, Di Vito L, Broglio F, Papotti M, Muccioli G, Dieguez $\mathrm{C}$ et al. Preliminary evidence that Ghrelin, the natural $\mathrm{GH}$ secretagogue (GHS)-receptor ligand, strongly stimulates $\mathrm{GH}$ secretion in humans. J Endocrinol Invest. 2000 Sep;23(8):493-5.

2. Cassoni $P$, Papotti $M$, Ghè $C$, Catapano $F$, Sapino $A$, Graziani A et al. Identification, characterization, and biological activity of specific receptors for natural (ghrelin) and synthetic growth hormone secretagogues and analogs in human breast carcinomas and cell lines. J Clin Endocrinol Metab. 2001 Apr;86(4):1738-45

3. Leite-Moreira AF, Soares J-B. Physiological, pathological and potential therapeutic roles of ghrelin. Drug Discov Today. 2007 Apr;12(7-8):276-88

4. Murata $M$, Okimura $Y$, lida $K$, Matsumoto $M$, Sowa $H$, Kaji $\mathrm{H}$ et al. Ghrelin modulates the downstream molecules of insulin signaling in hepatoma cells. J Biol Chem. 2002 Feb 15;277(7):5667-74.

5. Nanzer AM, Khalaf S, Mozid AM, Fowkes RC, Patel M V, Burrin JM et al. Ghrelin exerts a proliferative effect on a rat pituitary somatotroph cell line via the mitogen-activated protein kinase pathway. Eur J Endocrinol. 2004 Aug;151(2):233-40.

6. Stevanovic D, Milosevic V, Nesic D, Ajdzanovic V, Starcevic V, Severs WB. Central effects of ghrelin on serum growth hormone and morphology of pituitary somatotropes in rats. Exp Biol Med (Maywood). 2006 Nov;231(10):1610-5.

7. Milosević VL, Stevanović DM, Nesić DM, Sosić-Jurjević BT, Ajdzanović VZ, Starcević VP et al. Central effects of ghrelin on the adrenal cortex: a morphological and hormonal study. Gen Physiol Biophys. 2010 Jun;29(2):194-202.

8. Muccioli G, Ghè $C$, Ghigo MC, Papotti M, Arvat $E$, Boghen MF et al. Specific receptors for synthetic GH secretagogues in the human brain and pituitary gland. J Endocrinol. 1998 Apr;157(1):99-106.

9. Muccioli G, Papotti M, Locatelli V, Ghigo E, Deghenghi $R$. Binding of 125I-labeled ghrelin to membranes from human hypothalamus and pituitary gland. J Endocrinol Invest. 2001 Mar;24(3):RC7-9.

10. Kim K, Arai K, Sanno N, Osamura RY, Teramoto A, Shibasaki T. Ghrelin and growth hormone $(\mathrm{GH})$ secretagogue receptor (GHSR) mRNA expression in human pituitary adenomas. Clin Endocrinol (Oxf). 2001 Jun;54(6):759-68.

11. Jeffery PL, Herington AC, Chopin LK. The potential autocrine/paracrine roles of ghrelin and its receptor in hormone-dependent cancer. Cytokine Growth Factor Rev. 2003 Apr;14(2):113-22.

12. Delhanty PJD, van Koetsveld PM, Gauna C, van de Zande B, Vitale G, Hofland LJ et al. Ghrelin and its unacylated isoform stimulate the growth of adrenocortical tumor cells via an anti-apoptotic pathway. Am J Physiol Endocrinol Metab. 2007 Jul;293(1):E302-9.

13. Zhang W, Lin TR, Hu Y, Fan Y, Zhao L, Stuenkel EL et al Ghrelin stimulates neurogenesis in the dorsal motor nucleus of the vagus. J Physiol. 2004 Sep;559(Pt 3):729-37.
14. Zhang W, Zhao L, Lin TR, Chai B, Fan Y, Gantz I et al. Inhibition of adipogenesis by ghrelin. Mol Biol Cell. 2004 May;15(5):2484-91.

15. Baldanzi G, Filigheddu N, Cutrupi S, Catapano F, Bonissoni S, Fubini A et al. Ghrelin and des-acyl ghrelin inhibit cell death in cardiomyocytes and endothelial cells through ERK1/2 and PI 3-kinase/AKT. J Cell Biol. 2002 Dec;159(6):1029-37.

16. Tian $C$, Ye F, Wang L, Deng $Y$, Dong $Y$, Wang $X$ et al. Nitric oxide inhibits ghrelin-induced cell proliferation and ERK $1 / 2$ activation in GH3 cells. Endocrine. 2010 Dec;38(3):412-6.

17. Gahete MD, Rincón-Fernández D, Villa-Osaba A, Hormaechea-Agulla $D$, Ibáñez-Costa $A$, Martínez-Fuentes AJ et al. Ghrelin gene products, receptors, and GOAT enzyme: biological and pathophysiological insight. J Endocrinol. 2014 Jan;220(1):R1-24.

18. Papotti $M$, Ghè $C$, Cassoni $P$, Catapano $F$, Deghenghi $\mathrm{R}$, Ghigo $\mathrm{E}$ et al. Growth hormone secretagogue binding sites in peripheral human tissues. J Clin Endocrinol Metab. 2000 0ct;85(10):3803-7.

19. Volante M, Allia E, Fulcheri E, Cassoni P, Ghigo E, Muccioli $G$ et al. Ghrelin in Fetal Thyroid and Follicular Tumors and Cell Lines. Am J Pathol. 2003 Feb;162(2):645-54.

20. Cassoni P, Papotti M, Catapano F, Ghè C, Deghenghi R, Ghigo E et al. Specific binding sites for synthetic growth hormone secretagogues in non-tumoral and neoplastic human thyroid tissue. J Endocrinol. 2000 Apr;165(1):139-46.

21. van der Lely AJ, Tschöp M, Heiman ML, Ghigo E. Biological, physiological, pathophysiological, and pharmacological aspects of ghrelin. Endocr Rev. 2004 Jun;25(3):426-57.

22. Ghigo E, Broglio F, Arvat E, Maccario M, Papotti M, Muccioli G. Ghrelin: more than a natural GH secretagogue and/or an orexigenic factor. Clin Endocrinol (Oxf). 2005 Jan;62(1):1-17.

23. Maccarinelli G, Sibilia V, Torsello A, Raimondo F, Pitto M, Giustina A et al. Ghrelin regulates proliferation and differentiation of osteoblastic cells. J Endocrinol. 2005 Jan 1;184(1):249-56.

24. Tannenbaum GS, Epelbaum J, Bowers CY. Interrelationship between the novel peptide ghrelin and somatostatin/growth hormone-releasing hormone in regulation of pulsatile growth hormone secretion. Endocrinology. 2003 Mar;144(3):967-74.

Acceptance for editing: 2016-12-10 Acceptance for publication: 2016-12-26

Correspondence address: Małgorzata Kotwicka Department of Cell Biology oznan University of Medical Sciences 5D Rokietnicka Street, 60-806 Poznań, Poland phone: +48618547168 fax: +48 618547169 email:mkotwic@ump.edu.pl 